\title{
Bleeding of Common Carp (Cyprinus carpio) Improves Sensory Quality of Fillets and Slows Oxidative and Microbiological Changes During Refrigerated Aerobic Storage
}

\author{
Meta Sterniša ${ }^{1 *}$, Petr \\ Dvořak², Roman Lunda², \\ Zuzana Linhartova², \\ Sonja Smole Možina ${ }^{1}$ \\ and Jan Mraz ${ }^{2}$
}

'Biotechnical Faculty, Department of Food Science and Technology, University of Ljubljana, Jamnikarjeva 101, 1000 Ljubljana, Slovenia

${ }^{2}$ Faculty of Fisheries and Protection of Waters, South Bohemian Research Center of Aquaculture and Biodiversity of Hydrocenoses, Institute of Aquaculture and

Protection of Waters, University of South Bohemia in České Budějovice, Na Sádkách 1781, 37005 České Budějovice, Czech Republic

Received: 6 April 2018

Accepted: 8 August 2018

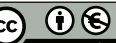

${ }^{*}$ Corresponding author:

Phone: +38613203762

E-mail: meta.sternisa@bf.uni-lj.si

ORCID IDs: 0000-0002-2414-3618 (Sterniša), 0000-0001-8326-0606

(Dvořak), 0000-0002-0437-585X (Lunda), 0000-0001-8246-6020 (Linhartova),

0000-0001-7949-8128 (Smole Možina), 0000-0003-3545-1269 (Mraz)

\section{SUMMARY}

Common carp (Cyprinus carpio) aquaculture is one of the most important and rapidly growing productions around the world. However, for consumers, carp is often not acceptable due to its distinctive colour and odour. In this study, we investigated the effects of bleeding of common carp on fillet quality. The obtained results show that carp bleeding by cutting the gill arches is an effective way of reducing the total haem content, which here decreased from (9.6 \pm 1.6$)$ in unbled carp to $(2.34 \pm 0.8) \mu \mathrm{mol} / \mathrm{kg}$ of haemoglobin in bled carp. Furthermore, fillets from bled carp showed reduced formation of primary and secondary lipid oxidation products and growth of microorganisms during 12 days of refrigerated aerobic storage. On the last day of storage, the amount of lipid hydroperoxides decreased from (88.9 \pm 4.2$)$ in unbled to $(62.1 \pm 2.9) \mu \mathrm{mol} / \mathrm{kg}$ of cumene hydroperoxide in bled carp, TBARS decreased from (4.2 \pm 0.5$)$ in unbled to $(2.6 \pm 0.4) \mu \mathrm{mol} / \mathrm{kg}$ of malondialdehyde in bled carp, mesophilic and psychrotrophic bacteria count decreased from (6.4 \pm 0.1$)$ and $(6.2 \pm 0.3)$ $\log \mathrm{CFU} / \mathrm{g}$ in unbled to (4.0 \pm 0.2$)$ and (4.2 \pm 0.2$) \log \mathrm{CFU} / \mathrm{g}$ in bled carp, respectively. These raw bled fillets showed increased lightness $L^{*}$, and reduced redness $a^{*}$ and yellowness $b^{*}$ compared to unbled fillets. Sensory analysis showed improved colour, odour and overall acceptability of bled raw fillets. Overall, bleeding improves the quality of carp fillets. Thus, inclusion of bleeding into processing of carp fillets has the potential to improve their acceptance by consumers and prolong their shelf-life.

Key words: common carp, bleeding, sensory quality, colour, lipid oxidation, microbiological quality

\section{INTRODUCTION}

Cyprinids are the most cultivated fish group worldwide and their production is constantly increasing. The production of common carp (Cyprinus carpio) through aquaculture reached 4556622 tonnes in 2016, which made carp the third most produced aquacultured fish worldwide, after grass carp (Ctenopharyngodon idellus) and silver carp (Hypophthalmichthys molitrix) (1). To provide fresh and safe common carp product of good quality, development and application of effective species-specific processes before, during and after slaughter are needed (2). For common carp, many studies that have investigated the pre-slaughter and slaughter processes emphasise the importance of reducing the stress for meat quality (3-5). One of the processes that can be included in the slaughter is bleeding, and for common carp this is most commonly achieved by cutting the gill arches or by direct gutting (2). However, to date, there have been no studies on the effects of bleeding on the quality of the fillet meat of common carp.

The presence of haem proteins in fish meat promotes lipid oxidation, discolouration, and odour development (6-8). Haem is part of both myoglobin and haemoglobin, with haemoglobin recognized as the better promoter of lipid oxidation (9). Iron is included in haem, and it is also an important source of nutrients for microorganisms (10). With the removal of the blood from the fish body, both erythrocytes (which contain the haemoglobin) and plasma are removed, which can be sources of lipid oxidation in fish (6). Thus, it can be expected that removal of blood from the fish meat will slow lipid oxidation and 
colour changes, improve the sensory characteristics, and inhibit microbial growth. Although different haem pro-oxidation mechanisms and factors that influence these have been investigated (11), reports of various effects of haem on lipid oxidation across different fish species indicate the need for further species-specific studies.

The colour and odour of the raw common carp meat are important factors for consumers. Despite its affordability and high nutritional value, it is often ignored because of its unattractive look (2). A more 'appealing' look and improved sensory characteristics, with emphasis on odour development, might improve the acceptability of common carp fillets. The effects of bleeding during the slaughter of common carp on fillet quality, in terms of instrumental colour, sensory characteristics, lipid oxidation and microbiological parameters during refrigerated aerobic storage were investigated. With selected methods, the influence of bleeding of carp on the quality of fillets was evaluated through comparison of bled and unbled carp. Only by confirming that bleeding of common carp is the key processing step to improve the quality, further optimization of the process and research of mechanisms behind it can be done.

\section{MATERIALS AND METHODS}

\section{Fish and experimental plan}

Four-year-old common carp ( $N=80$; body mass ( $2395.60 \pm$ $287.02) \mathrm{g}$ ) that were bred in pond aquaculture and purged for 2 months were bought from a local producer (České Budějovice, Czech Republic) in November 2016. These were transported to the Institute of Aquaculture and Protection of Waters, University of South Bohemia, České Budějovice, Czech Republic (authorisation for use of experimental animals: 35085/2016-MZE-17214). These carp were rested for $24 \mathrm{~h}$ in a water tank $\left(6^{\circ} \mathrm{C}, 96 \% \mathrm{O}_{2}\right)$ before the start of the experiments.

All of the carp were killed by a blow to the head. Forty randomly selected carp were bled by cutting the gill arches and hanging them vertically with the head down for $30 \mathrm{~min}$, to allow gravity to help the bleeding. After that, all of the carp were stored in ice, positioned straight, with their bodies upright (i.e. natural swimming position), in a refrigerated chamber. Further processing was performed after $22 \mathrm{~h}$, to let the blood coagulate and to prevent bleeding during the gutting in the unbled group. All of these carp were then gutted, descaled and filleted by the same person, to ensure consistency. The mean filleted yield was $(42.24 \pm 2.14) \%$. The fillets were packed individually in non-sealed polyethylene vacuum bags (size $250 \mathrm{~mm} \times 400 \mathrm{~mm}$ ) to prevent drying of the fillet surface and stored in a straight horizontal position (i.e. 'flat') in a refrigerated chamber (NORDline UR600; Nosreti, Ostrava, Czech Republic) at $(2.0 \pm 0.5)^{\circ} \mathrm{C}$.

The analyses of these carp fillets were carried out on days $1,3,6,9$ and 12 of storage. Randomly selected right fillets from the bled and unbled groups ( $N=6$, from each group) were used for colour analyses. Similarly, randomly selected left fillets were used for sensory evaluation ( $N=6$, from each group), and right fillets for chemical and microbiological analyses ( $N=6$, from each group). For microbiological analyses, approximately the first $5 \mathrm{~cm}$ of the fillets were cut and used fresh. The haem content analysis was carried out only on light dorsal muscle, and the rest of the fillets were used for lipid oxidation analysis, after being homogenised and stored at $-80^{\circ} \mathrm{C}$ (Igloo U570; Telstar, Sant Cugat, Spain) until analysis.

\section{Chemicals}

Chloroform, methanol, ammonium thiocyanate, iron(II) sulphate, cumene hydroperoxide, bovine haemoglobin, 2,6-di-tert-butyl-4-methylphenol (BHT), 1,1,3,3-tetraethoxypropane (TEP), phosphoric acid, plate count agar, peptone water (all from Sigma-Aldrich, Merck, St. Louis, MO, USA), sodium chloride, acetone (both from Lach-Ner, Neratovice, Czech Republic), hydrochloric acid, barium chloride dihydrate (both from Penta, Prague, Czech Republic), trichloracetic acid (TCA; Fisher Chemical, Leichestershire, UK), 2-thiobarbituric acid (TBA; Merck, Darmstadt, Germany) were used.

\section{Colour analysis}

The colour of the carp fillet meat was measured at three locations along the dorsal part of each fillet, above the lateral line (i.e. frontal, middle, caudal), using a colour spectrophotometer (CM-600d; Konica Minolta, Tokyo, Japan). Each spot was measured in duplicate. Colour space CIELAB was used, with measurement of the colour parameters $L^{*}$ (lightness, from black [0] to white [100]), $a^{*}$ (redness, from green [-a] to red $[+a]$ ), and $b^{*}$ (yellowness, from blue $[-\mathrm{b}]$ to yellow $[+b]$ ).

\section{Sensory evaluation}

The sensory qualities of the raw and cooked meat of the carp fillets were evaluated by a panel of ten members of the staff of the Institute of Aquaculture and Protection of Waters. These were carried out in individual cubicles, to separate the panellists from each other, and under controlled conditions of temperature, light and humidity (12). Each sample was labelled randomly with a 3- or 4-digit code, and the evaluations were performed in triplicate. During the evaluations, there was a 40-min break, and with each new assessment, the same sample was evaluated under a different code.

The whole raw carp fillets were examined for texture (from 5 , being firm, to 1 , being soft), colour (from 5 , without discolouration, to 1, with extreme discolouration), odour (from 5 , being extremely desirable, to 1 , being extremely undesirable), and overall acceptability (from 5, being extremely acceptable, to 1 , being extremely unacceptable) (13).

To evaluate the cooked meat of the carp fillets, they were cut into small pieces (approx. $2 \mathrm{~cm} \times 2 \mathrm{~cm}$ ). Each sample comprised three pieces of meat, with each from a different part of the fillets. These were placed in 0.2-litre glass jars, and cooked in an electric oven for $15 \mathrm{~min}$ at $150^{\circ} \mathrm{C}$, without any added 
salt, oil or spices (14). The panellists evaluated (from 5, being extremely desirable, to 1 , being extremely undesirable) four parameters of the cooked carp fillet meat: flavour, odour, aftertaste and consistency (from 5, being firm, to 1, being soft).

\section{Haem content}

Haem protein can originate from myoglobin or haemoglobin, although myoglobin is not present in light muscle $(6,15,16)$. Therefore, only raw light muscle was used to determine the fillet meat haem content, using acidified acetone according to a previously described method $(16,17)$. Briefly, $5 \mathrm{~g}$ of sample were homogenised (Ultra Turrax T 18 basic; IKA, Staufen im Breisgau, Germany) with $20 \mathrm{~mL}$ of acid acetone for $15 \mathrm{~s}$ and incubated for $1 \mathrm{~h}$ in the refrigerator (NORDline UR600; Nosreti). Afterwards, homogenate was filtered through Whatman no. 1 filter paper and centrifuged (Hereus Megafuge 16R; Thermo Scientific, Waltham, MA, USA) at $10000 \times g$ for $15 \mathrm{~min}$. Absorbance was measured at $640 \mathrm{~nm}$ (DR2800; Hach Lange GmbH, Düsseldorf, Germany). A standard curve was prepared with bovine haemoglobin, and the data were expressed as molal concentration of haemoglobin in $\mu \mathrm{mol} / \mathrm{kg}$. Each sample was analysed in duplicate.

\section{Lipid oxidation parameters}

Lipid hydroperoxides and thiobarbituric acid reactive substances (TBARS) were determined using previously described spectrophotometrical methods $(18,19)$. For lipid hydroperoxides, $11 \mathrm{~mL}$ of $65 \%$ chloroform in methanol were added to 1 $\mathrm{g}$ of sample, homogenised (Ultra Turrax T 18 basic; IKA) for 3 min and filtered. To $7 \mathrm{~mL}$ of supernatant, $2 \mathrm{~mL}$ of $0.5 \% \mathrm{NaCl}$ were added, vortexed (Vortex GENIUS 3; IKA) and centrifuged at $3000 \times g$ for $5 \mathrm{~min}$. To $5 \mathrm{~mL}$ of lower phase, $0.25-\mu \mathrm{L}$ solution of ammonium thiocyanate and iron(II) chlorid (for detailed instructions of preparation see Shanta and Decker (18)) were added and incubated for $20 \mathrm{~min}$. Absorbance was measured at $500 \mathrm{~nm}$. The standard curve was prepared using cumene hydroperoxide (CHP), and the data were expressed in $\mu \mathrm{mol}$ CHP/kg (18). For TBARS, $0.2 \mathrm{~mL}$ of $0.02 \mathrm{M} \mathrm{BHT}$ and $9.1 \mathrm{~mL}$ of 10 $\%$ TCA in $0.2 \mathrm{M} \mathrm{H}_{3} \mathrm{PO}_{4}$ were added to $1 \mathrm{~g}$ of sample, homogenised for $30 \mathrm{~s}$ and filtered. To $1.5 \mathrm{~mL}$ of supernatant, the same volume of TBA was added and incubated overnight in the dark at room temperature. Absorbance was measured at 530 $\mathrm{nm}$. The standard curve was prepared with TEP, and the data were expressed as molal concentration of malondialdehyde (MDA) in $\mu \mathrm{mol} / \mathrm{kg}$ (19). Each sample was analysed in duplicate.

\section{Microbiological analysis}

To determine the total numbers of aerobic mesophilic and psychrotrophic bacteria, analyses were done according to standardised procedures $(20,21)$. Shortly, approx. $10 \mathrm{~g}$ of raw fillet meat were taken aseptically from the dorsal muscle and homogenised for 3 min (Masticator Classic Panoramic IU 500; IUL Instruments, Barcelona, Spain) with $90 \mathrm{~mL}$ of $0.1 \%$ peptone water. Serial dilutions were done and plated on agar plates. For mesophilic bacteria, the plates were incubated (NB $203 \mathrm{XL}$; $\mathrm{N}$-Biotek, Pyeongcheon-ro, South Korea) for 3 days at $30^{\circ} \mathrm{C}$, and for psychrotrophic bacteria, they were incubated for 10 days at $6.5^{\circ} \mathrm{C}$ (NORDline UR600; Nosreti). These data were expressed as logarithmic value of colony-forming units (log CFU) per $\mathrm{g}$ of raw carp fillet meat. Each sample was analysed in duplicate.

\section{Statistical analysis}

The colour, haem content, lipid oxidation and microbiological parameters are presented as mean value \pm standard deviation. Data assumptions of normality (Shapiro Wilk test) and homogeneity of variance (Levene's test) were met. These data were analysed using general linear models to test the influences of group (bled, unbled) and time (storage days 1, 3, 6, 9, 12 ), and their interactions. For colour, this also included location of measurement (frontal, middle, caudal). Pearson's correlation coefficient was calculated to correlate haem content with lipid oxidation and microbiological parameters. The sensory analysis data were obtained on the ordinal scale, and are presented as median and interquartile range. These data were further analysed using nonparametric Mann-Whitney $U$ test to compare each evaluated parameter between bled and unbled group on each assessment day, and with Kruskal-Wallis $\mathrm{H}$ test to compare sensory attributes between sampling days. Calculated probability $\mathrm{p} \leq 0.05$ was considered as statistically significant. All statistical analyses were carried out following the instructions $(22,23)$. Statistical analyses were performed using the SPSS Statistics V23 (24).

\section{RESULTS AND DISCUSSION}

\section{Colour of raw carp fillet meat}

The bleeding of the carp during slaughter significantly affected the colour of the carp fillet meat ( $p<0.001$; Fig. 1 , Table 1 and Table 2). The raw bled fillets showed higher $L^{*}$ (lightness) and lower $a^{*}$ (redness) and $b^{*}$ (yellowness) than the raw unbled fillets. Both $a^{*}$ and $b^{*}$ increased significantly over time $(p<0.001)$; however, $L^{*}$ did not change significantly in any of the groups. Higher whiteness was reported for bled Atlantic cod (Gadus morhua) than the unbled cod with calculated whiteness index (71.29 bled, 64.68 unbled) from measurements of hyperspectral image (25). Similarly, higher $L^{*}$ was observed in the immediately bled $\left(L^{*} 47\right)$ Atlantic salmon (Salmo salar) than in those bled after $12 \mathrm{~h}$, which can be considered as an unbled $\left(L^{*} 44\right)$ group (26). Similarly again, more pronounced redness was reported of unbled fillets of yellowtail (Seriola quinqueradiata) and Asian seabass (Lates calcarifer) (7,27). Also, Digre et al. (28) observed significantly higher $L^{*}$ and lower $a^{*}$ values in gill cutting than in direct gutting as bleeding method.

There were also differences between the three sample locations of the raw carp fillet meat used for the colour measurements. The $L^{*}$ at all three locations was comparable within each group ( $p>0.05)$. On the contrary, location significantly 
affected both $a^{*}$ and $b^{*}$, which were significantly higher at the caudal location than at the other two locations $(p<0.001)$. A similar pattern was described for Atlantic $\operatorname{cod}(25,28)$, where whiteness index in the belly part was higher than in loins. These changes observed for the whole carp fillet surface colour might be partially due to fat deposition, which is lower towards the tail section (26). Furthermore, the thickness of the fillet is reduced in the tail section, which will result in an additional contribution to the fillet colour from the dark muscle, compared with the frontal and middle sections.

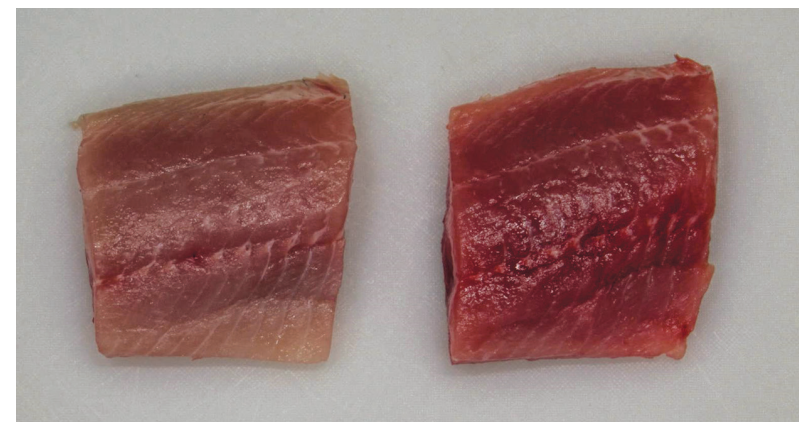

Fig. 1. Representative photographs of bled (left) and unbled (right) pieces of common carp dorsal muscle

\section{Sensory quality}

The sensory evaluations of the raw bled and unbled carp fillet meat showed significant differences (Fig. 2 and Table 3; $p<0.05$ ), with the raw bled fillets evaluated with better (i.e. higher) overall scores than the raw unbled fillets. The greatest improvements between the groups were seen in colour evaluation of the bled fillets and overall acceptability, where two points of difference were observed. Colour improvement and less discolouration were also described as main sensory characteristics improved by bleeding of yellowtail (7), Atlantic cod (25) and skipjack (Katsuwonus pelamis) (29). Therefore, bleeding is efficient processing step for improvement of fillet colour, which is one of the important factors for consumer acceptability of carp meat. Another very important factor for sensory acceptability of carp is odour, which was also improved by one score on day 6 and 9 . Also for Asian seabass, more pronounced odour of unbled fillets was reported than of bled fillets, with odour score on days 9 and 15 of storage reaching average of 5 and 10 in unbled, and 2 and 7 in bled cod, respectively (27). Also in sensory evaluation of rancid odour of rainbow trout (Onchorhynchus mykiss) and Atlantic mackerel (Scomber scombrus), it was significantly greater in unbled samples. After 15 days of storage, rancid odour was detected in $60 \%$ of unbled and $30 \%$ of bled trout. For Atlantic mackerel this was $100 \%$ for unbled and $40 \%$ for bled on day 8 of refrigerated storage (6). There were no changes in the texture of raw carp fillets. Similar was also shown for red sea bream (Pagrus major), flatfish (Paralichthys olivaceus) and rudder fish (Girella punctata) (30), all of which are demersal fish, like carp. Bleeding of common carp had a significant effect on improving the sensory acceptability of raw carp fillets.

For the cooked carp fillet meat, the bled and unbled meat showed comparable sensory qualities on days 1 and 3 of storage (Fig. 2 and Table 3; p>0.05). However, there were improvements (i.e. higher scores) after bleeding in all of the characteristics by day 6 of storage; the improvement of consistency and flavour was significant $(p<0.05)$. On day 12 , the cooked meat samples were considered inedible, and so the sensory analysis was not performed. Therefore, the last sensory evaluation of the cooked meat was on day 9 , with no significantly different

Table 1. CIELAB colour space parameters measured at the three locations in the meat of the raw bled and unbled carp fillets after up to 12 days of refrigerated aerobic storage

\begin{tabular}{|c|c|c|c|c|c|c|c|}
\hline \multirow{3}{*}{$\begin{array}{l}\text { Colour } \\
\text { parameter }\end{array}$} & \multirow{3}{*}{$\frac{t \text { (storage) }}{\text { day }}$} & \multicolumn{6}{|c|}{ Raw carp fillet meat } \\
\hline & & \multicolumn{3}{|c|}{ Bled } & \multicolumn{3}{|c|}{ Unbled } \\
\hline & & Frontal & Middle & Caudal & Frontal & Middle & Caudal \\
\hline \multirow[t]{5}{*}{$L^{*}$} & 1 & $41.7 \pm 3.7$ & $42.2 \pm 2.3$ & $42.1 \pm 1.8$ & $37.8 \pm 1.9$ & $37.8 \pm 1.6$ & $38.1 \pm 3.8$ \\
\hline & 3 & $44.0 \pm 5.3$ & $41.5 \pm 1.9$ & $42.7 \pm 1.6$ & $36.8 \pm 2.3$ & $37.5 \pm 1.8$ & $36.3 \pm 2.8$ \\
\hline & 6 & $43.8 \pm 4.7$ & $42.7 \pm 1.9$ & $43.3 \pm 1.5$ & $37.0 \pm 1.7$ & $37.6 \pm 1.4$ & $37.0 \pm 2.4$ \\
\hline & 9 & $44.5 \pm 3.8$ & $42.4 \pm 1.2$ & $44.8 \pm 1.1$ & $38.3 \pm 1.6$ & $39.6 \pm 3.0$ & $37.9 \pm 1.7$ \\
\hline & 12 & $44.8 \pm 3.9$ & $42.5 \pm 1.9$ & $43.6 \pm 1.2$ & $37.8 \pm 2.2$ & $37.6 \pm 1.00$ & $37.9 \pm 2.8$ \\
\hline \multirow[t]{5}{*}{$a^{*}$} & 1 & $-1.4 \pm 0.4$ & $-1.7 \pm 0.4$ & $-1.3 \pm 0.7$ & $2.0 \pm 1.2$ & $1.6 \pm 1.4$ & $3.3 \pm 2.3$ \\
\hline & 3 & $-1.7 \pm 0.8$ & $-2.0 \pm 0.6$ & $-1.1 \pm 0.5$ & $3.2 \pm 2.0$ & $2.45 \pm 2.0$ & $5.9 \pm 2.1$ \\
\hline & 6 & $-1.5 \pm 0.7$ & $-1.9 \pm 0.6$ & $-0.9 \pm 0.9$ & $3.3 \pm 1.5$ & $3.0 \pm 2.4$ & $6.0 \pm 2.7$ \\
\hline & 9 & $-1.0 \pm 0.9$ & $-1.2 \pm 1.2$ & $0.1 \pm 1.1$ & $4.6 \pm 1.8$ & $3.6 \pm 1.7$ & $7.5 \pm 2.6$ \\
\hline & 12 & $-1.6 \pm 0.9$ & $-1.3 \pm 1.0$ & $0.2 \pm 1.1$ & $2.9 \pm 1.2$ & $3.3 \pm 1.1$ & $5.4 \pm 1.9$ \\
\hline \multirow[t]{5}{*}{$b^{*}$} & 1 & $2.7 \pm 1.1$ & $2.5 \pm 1.5$ & $3.5 \pm 0.8$ & $5.6 \pm 0.8$ & $5.5 \pm 1.2$ & $5.9 \pm 0.9$ \\
\hline & 3 & $3.4 \pm 1.9$ & $2.8 \pm 1.0$ & $4.9 \pm 0.4$ & $6.4 \pm 1.8$ & $6.4 \pm 1.6$ & $7.3 \pm 1.4$ \\
\hline & 6 & $4.0 \pm 1.5$ & $2.3 \pm 0.7$ & $4.7 \pm 0.8$ & $6.5 \pm 1.3$ & $6.4 \pm 1.7$ & $7.4 \pm 1.2$ \\
\hline & 9 & $4.2 \pm 1.1$ & $3.6 \pm 1.1$ & $5.8 \pm 1.3$ & $6.8 \pm 1.3$ & $6.9 \pm 0.98$ & $8.7 \pm 1.4$ \\
\hline & 12 & $4.4 \pm 1.3$ & $4.4 \pm 0.8$ & $6.3 \pm 0.9$ & $5.8 \pm 1.1$ & $7.0 \pm 0.5$ & $7.3 \pm 1.2$ \\
\hline
\end{tabular}

Data are mean value \pm standard deviation. $L^{*}=$ significantly affected by group $(p<0.001), a^{*}=$ significantly affected by group, location and time $(p<0.001)$; significant interactions between group and location $(p<0.01)$ and group and time $(p<0.05), b^{*}=$ significantly affected by group, location and time $(p<0.001)$; significant interactions between group and location $(p<0.05)$ 
Table 2. Effect of bleeding, time and their interaction on quality attributes and the effect of location and interactions on colour parameters of bled and unbled carp fillets during storage using general linear models

\begin{tabular}{|c|c|c|c|c|c|c|c|}
\hline $\begin{array}{l}\text { Quality } \\
\text { attribute }\end{array}$ & Bleeding & Time & Location & Bleeding $\times$ time & Bleeding $\times$ location & Time $\times$ location & Bleeding $\times$ time $\times$ location \\
\hline$L^{*}$ & $* * *$ & NS & NS & NS & NS & NS & NS \\
\hline$a^{*}$ & $* * *$ & $* * *$ & $* * *$ & * & ** & NS & NS \\
\hline$b^{*}$ & $* * *$ & $* * *$ & $* * *$ & NS & * & NS & NS \\
\hline $\begin{array}{c}\text { Lipid } \\
\text { hydroperoxides }\end{array}$ & $* * *$ & $* * *$ & - & $* * *$ & - & - & - \\
\hline TBARS & $* * *$ & $* * *$ & - & $* * *$ & - & - & - \\
\hline $\begin{array}{c}\text { Mesophilic } \\
\text { bacteria }\end{array}$ & $* * *$ & $* * *$ & - & $* * *$ & - & - & - \\
\hline $\begin{array}{l}\text { Psychrotrophic } \\
\text { bacteria }\end{array}$ & $* * *$ & $* * *$ & - & $* * *$ & - & - & - \\
\hline
\end{tabular}

Within each row, for each factor and their interactions: ${ }^{*} p<0.05,{ }^{* *} p<0.01,{ }^{* * *} p<0.001$; NS=not significant $(p>0.05)$. TBARS=thiobarbituric acid reactive substances



Fig. 2. Sensory quality of the raw and cooked bled (shades of blue) and unbled (shades of red) common carp fillets on storage days 1,3 , 6 and 9 under refrigerated aerobic storage attributes between the groups ( $p>0.05$ ). The sensory evaluation of cooked fish meat has not been studied in the previous studies of the influence of bleeding on fish meat quality. The most pronounced difference was observed on day 6 , where there was an improvement in the sensory evaluation of the bled meat. So, bleeding also had a positive effect on the cooked carp meat, which further increases the possibility of better acceptability of carp meat by the consumers.

\section{Total haem content}

Total haem content was determined in all of the raw fillet meat samples to show the effectiveness of the bleeding. As the haem content in the raw bled and unbled fillet meat did not change over time, the data from all of the sampling days were combined. In the raw bled meat, the haem content of haemoglobin of $(2.4 \pm 0.8) \mu \mathrm{mol} / \mathrm{kg}$ was significantly lower $(p<0.001)$ than in the raw unbled meat $((9.6 \pm 1.6) \mu \mathrm{mol} / \mathrm{kg})$. This confirmed

Table 3. Sensory attribute comparison of raw and cooked carp fillets between bled and unbled group during storage using Mann-Whitney U test

\begin{tabular}{|c|c|c|c|c|c|c|c|c|c|c|c|c|c|c|c|}
\hline \multirow{3}{*}{ Fillet } & \multirow{3}{*}{$\begin{array}{l}\text { Sensory } \\
\text { attribute }\end{array}$} & & \multicolumn{12}{|c|}{$t /$ day } & \multirow{3}{*}{$\frac{\mathrm{T}}{\mathrm{H}}$} \\
\hline & & & \multicolumn{3}{|c|}{1} & \multicolumn{3}{|c|}{3} & \multicolumn{3}{|c|}{6} & \multicolumn{3}{|c|}{9} & \\
\hline & & & $\mathrm{Me}$ & IQR & U & $\mathrm{Me}$ & IQR & U & $\mathrm{Me}$ & IQR & U & $\mathrm{Me}$ & IQR & U & \\
\hline \multirow[t]{8}{*}{ Raw } & \multirow[t]{2}{*}{ Texture } & B & 5 & 1 & \multirow[t]{2}{*}{ NS } & 5 & 1 & \multirow[t]{2}{*}{ NS } & 4 & 1 & \multirow[t]{2}{*}{ NS } & 4 & 1 & \multirow[t]{2}{*}{ NS } & $* * *$ \\
\hline & & UB & 5 & 1 & & 4 & 1 & & 4 & 0 & & 3 & 0 & & *** \\
\hline & \multirow[t]{2}{*}{ Colour } & B & 5 & 1 & \multirow[t]{2}{*}{$* * *$} & 5 & 1 & \multirow[t]{2}{*}{$* * *$} & 5 & 1 & \multirow[t]{2}{*}{$* * *$} & 4 & 1 & \multirow[t]{2}{*}{$* * *$} & $* *$ \\
\hline & & UB & 3 & 1 & & 3 & 1 & & 3 & 0.75 & & 3 & 1 & & $* *$ \\
\hline & \multirow[t]{2}{*}{ Odour } & B & 5 & 1 & \multirow[t]{2}{*}{ NS } & 5 & 0 & \multirow[t]{2}{*}{ NS } & 4 & 0.38 & \multirow[t]{2}{*}{$* * *$} & 3 & 1 & \multirow[t]{2}{*}{$* * *$} & $* * *$ \\
\hline & & UB & 5 & 1 & & 5 & 1 & & 3 & 1 & & 2.5 & 1 & & *** \\
\hline & \multirow{2}{*}{$\begin{array}{c}\text { Overall } \\
\text { acceptability }\end{array}$} & $B$ & 5 & 0 & \multirow[t]{2}{*}{$* * *$} & 5 & 0 & \multirow[t]{2}{*}{$* * *$} & 4 & 0.88 & \multirow[t]{2}{*}{$* * *$} & 3.75 & 1 & \multirow[t]{2}{*}{$* * *$} & *** \\
\hline & & UB & 3 & 1 & & 4 & 2 & & 3.75 & 1 & & 3 & 1 & & $* * *$ \\
\hline \multirow[t]{8}{*}{ Cooked } & \multirow[t]{2}{*}{ Consistency } & $B$ & 5 & 0.5 & \multirow[t]{2}{*}{ NS } & 4.5 & 1.38 & NS & 4.5 & 0.88 & $* *$ & 3.5 & 1 & NS & $* * *$ \\
\hline & & UB & 5 & 0.5 & & 4.5 & 1 & & 4 & 0.5 & & 3.5 & 1 & & $* * *$ \\
\hline & Odour & $B$ & 4.75 & 1 & NS & 4.5 & 1 & NS & 4.5 & 0.5 & NS & 3 & 1 & NS & $* * *$ \\
\hline & & UB & 4.5 & 0.5 & & 4.25 & 1.5 & & 4 & 1 & & 3 & 1 & & $* * *$ \\
\hline & Flavour & $B$ & 4.5 & 1.38 & NS & 4 & 0.88 & NS & 4.5 & 0.5 & * & 3 & 1 & NS & $* * *$ \\
\hline & & UB & 4.5 & 1 & & 4.25 & 1.88 & & 3.75 & 0.88 & & 2.75 & 1 & & $* * *$ \\
\hline & Aftertaste & $B$ & 4.5 & 1 & NS & 4 & 1.5 & NS & 4.5 & 1.38 & NS & 3 & 1 & NS & $* *$ \\
\hline & & UB & 4.5 & 1 & & 4.5 & 1.38 & & 3.75 & 1.38 & & 3 & 1 & & $* * *$ \\
\hline
\end{tabular}

$\mathrm{B}=$ bled, $\mathrm{UB}=$ unbled, $\mathrm{T}=$ comparison of sensory attributes between sampling days, Me=median, $\mathrm{IQR}=$ interquartile range, $\mathrm{U}=\mathrm{results}$ of $\mathrm{Mann}$ -Whitney $U$ test, $H=$ results of Kruskal-Wallis $H$ test. For $U$ and $H:{ }^{*} p<0.05,{ }^{* *} p<0.01,{ }^{* * *} p<0.001$; NS=not significant $(p>0.05)$ 
the effectiveness of bleeding and successful removal of residual blood from carp meat. The obtained data correspond to the data from other studies of bleeding efficiency $(6,16,27,31)$. Bleeding lowered the haem content of haemoglobin from $(11.1 \pm 4.6)$ in unbled to $(7.4 \pm 2.9) \mu \mathrm{mol} / \mathrm{kg}$ in bled rainbow trout, from $(6.1 \pm 1.0)$ in unbled to $(3.4 \pm 0.5) \mu \mathrm{mol} / \mathrm{kg}$ in bled Atlantic mackerel (6), and from $(1.0 \pm 0.2)$ in unbled to $(0.07 \pm 0.05) \mathrm{mg} / \mathrm{kg}$ in bled skipjack (31). In bled Asian seabass, total haem content was evaluated as absorbance at $525 \mathrm{~nm}$, and it was lower by 0.1 in bled than in unbled seabass (27). Counting blood spots in Atlantic salmon and Atlantic cod proved to be reliable, non-invasive method for evaluation of residual blood $(16,25,26)$, and in both fish significantly higher number of blood spots was found in unbled than in bled fish. However, contrary to the present data for raw carp meat, the haem content in Asian seabass was reported to decrease with longer storage time. This is due to the degradation of the fish meat, which lowers the solubility of the haem proteins $(11,32)$.

Haemoglobin is a protein made up of four haem subunits, each carrying iron which enables its main function - transfer of oxygen (11). At the same time, haemoglobin also gives red colour to the blood, and consequently to the tissue in which it is present. Therefore, effective bleeding reduces the amount of residual blood in fish meat, and the colour of the meat is improved as there is less or no discoloration as a result of the breakdown of haemoglobin. Additionally, the removal of blood and thus haemoglobin is positively related to other sensory attributes, especially odour and overall acceptability of carp fillets. Thus, removal of haemoglobin from carp meat positively affects its sensory quality.

\section{Lipid oxidation}

The data for the two lipid oxidation parameters of lipid hydroperoxides and TBARS are given in Table 2 and Table 4. The amount of lipid hydroperoxides significantly increased in both raw bled and unbled carp fillet meat with increased storage time $(p<0.001)$. Apart from their increase in both groups over time, the lipid hydroperoxides in the bled fillets were significantly lower during all of the sampling days than in the unbled fillets $(p<0.001)$. Increases in lipid hydroperoxides were also reported in Asian seabass over 15 days of storage on ice with similar initial and final values in the bled and unbled seabass on day 0 and 15 (4.5 and $14 \mathrm{mg} / \mathrm{kg}$ respectively), but with significantly lower values in the bled seabass meat during storage (27). However, contrary to the present study on carp, the lipid hydroperoxides in the Asian seabass reached a plateau on day 9 in the unbled fillets, and on day 12 in the bled fillets. Conversely, for yellowtail muscle, the effects of bleeding on the lipid hydroperoxides depended on the muscle type: bled light $(0.08 \mu \mathrm{mol} / \mathrm{g})$ and dark ( 3 $\mu \mathrm{mol} / \mathrm{g})$ muscle were more prooxidative than unbled light $(0.04$ $\mu \mathrm{mol} / \mathrm{g}$ ) and dark muscle ( $4 \mu \mathrm{mol} / \mathrm{g})$ after 72 hours ( 7$)$. In washed mince of bighead carp (Hypophthalmichthys nobilis), the added haemoglobin was shown as more pro-oxidative than the added myoglobin, reaching over $80 \mu \mathrm{mol} / \mathrm{kg}$ of CHP after one day of storage, which was not reached in myoglobin-treated samples during all 9 days of observation. On day 3 of storage in the mince treated with haemoglobin, values grew to over $200 \mu \mathrm{mol} / \mathrm{kg}$ of CHP and kept increasing until day 5, followed by slight decrease (33). This confirms the importance of muscle type and species specificity for process of lipid oxidation. For common carp, the removal of blood and thus highly pro-oxidative haemoglobin proved to be positively correlated $(R=0.649, p=0.003)$ with the formation of primary oxidation products.

TBARS also increased in both the raw bled and unbled carp fillet meat with increased storage time, with significantly lower values again for the bled fillets $(p<0.001)$. The difference here was more pronounced from the third storage day onwards. Similar changes of TBARS were reported in previous research on Asian seabass bleeding, where after 15 days of storage, TBARS reached $10 \mathrm{mg} / \mathrm{mg}$ of MDA in bled and $32 \mathrm{mg} / \mathrm{kg}$ of MDA in unbled seabass (27). In rainbow trout, TBARS were greater in the unbled group from day 7 to 15 , and in mackerel already from day 2 , but with no significance due to high variations (6). In skipjack after 2 days of storage at $2{ }^{\circ} \mathrm{C}$, no changes were seen in MDA levels, with $(1.53 \pm 0.29) \mu \mathrm{mol} / \mathrm{kg}$ of MDA in unbled and $(1.35 \pm 0.17) \mu \mathrm{mol} /$ $\mathrm{kg}$ of MDA in bled fish (31). No high variations were observed in TBARS in common carp; additionally, positive correlation $(R=0.763, p<0.001)$ between haem content and TBARS confirms the efficiency of bleeding for delaying secondary lipid oxidation.

\section{Microbiological growth}

The data for the colony counts of mesophilic and psychrotrophic bacteria in the raw bled and unbled carp fillet meat at 6.5 and $30^{\circ} \mathrm{C}$, respectively, are given in Table 2 and Table 4. The bleeding and storage time significantly affected the growth of

Table 4. Lipid oxidation and microbiological parameters of the raw bled and unbled carp fillets after up to 12 days of refrigerated aerobic storage

\begin{tabular}{|c|c|c|c|c|c|c|c|c|}
\hline \multirow{4}{*}{$\frac{t \text { (storage) }}{\text { day }}$} & \multicolumn{4}{|c|}{ Lipid oxidation parameter } & \multicolumn{4}{|c|}{ Microbiological parameter } \\
\hline & \multirow{2}{*}{\multicolumn{2}{|c|}{$\frac{n(\mathrm{CHP}) / \mathrm{m} \text { (fillet) }}{\mu \mathrm{mol} / \mathrm{kg}}$}} & \multirow{2}{*}{\multicolumn{2}{|c|}{$\frac{n(\mathrm{MDA}) / \mathrm{m} \text { (fillet) }}{\mu \mathrm{mol} / \mathrm{kg}}$}} & \multirow{2}{*}{\multicolumn{2}{|c|}{$\frac{N(\text { mesophilic bacteria) }}{\log \text { CFU } / g}$}} & \multirow{2}{*}{\multicolumn{2}{|c|}{$\frac{N(\text { psychrotrophic bacteria }}{\log \text { CFU } / g}$}} \\
\hline & & & & & & & & \\
\hline & Bled & Unbled & Bled & Unbled & Bled & Unbled & Bled & Unbled \\
\hline 1 & $12.4 \pm 1.7$ & $16.4 \pm 1.8$ & $0.4 \pm 0.1$ & $0.6 \pm 0.2$ & $1.9 \pm 0.1$ & $1.7 \pm 0.1$ & $1.8 \pm 0.1$ & $1.6 \pm 0.1$ \\
\hline 3 & $21.6 \pm 2.2$ & $33.5 \pm 3.5$ & $0.5 \pm 0.2$ & $1.2 \pm 0.3$ & $2.7 \pm 0.1$ & $3.1 \pm 0.1$ & $2.5 \pm 0.2$ & $2.9 \pm 0.1$ \\
\hline 6 & $26.4 \pm 1.6$ & $37.0 \pm 2.5$ & $2.2 \pm 0.1$ & $2.7 \pm 0.2$ & $3.1 \pm 0.2$ & $4.1 \pm 0.1$ & $3.2 \pm 0.2$ & $3.9 \pm 0.1$ \\
\hline 9 & $36.1 \pm 1.8$ & $55.9 \pm 2.8$ & $2.1 \pm 0.3$ & $2.7 \pm 0.3$ & $3.3 \pm 0.2$ & $4.3 \pm 0.1$ & $3.8 \pm 0.2$ & $4.2 \pm 0.1$ \\
\hline 12 & $62.1 \pm 2.9$ & $88.9 \pm 4.2$ & $2.6 \pm 0.4$ & $4.2 \pm 0.5$ & $4.0 \pm 0.2$ & $6.4 \pm 0.1$ & $4.2 \pm 0.2$ & $6.2 \pm 0.3$ \\
\hline
\end{tabular}

Data are mean values \pm standard deviation. $\mathrm{CHP}=$ cumene hydroperoxide, $\mathrm{MDA}=$ malondialdehyde, $\mathrm{CFU}=$ colony-forming units. Parameters significantly affected by group, time and their interactions $(p<0.001)$ 
these bacteria in the raw carp fillets $(p<0.001)$. On the first sampling day, the mesophilic and psychrotrophic bacteria were higher in the bled group. This was probably due to the cut for the bleeding and the overnight storage of the carp, which will have given the bacteria on the surface of the carp an easy way to invade the raw carp meat. On all of the other sampling days, the mesophilic and psychrotrophic bacteria were higher in the unbled group. Such slowing of growth of mesophilic and psychrotrophic bacteria in raw fillets of bled fish was also reported for Asian seabass, where initial counts were around 3 log CFU/g (27), showing higher initial bacterial contamination than the common carp initial load bellow 2 log CFU/g. After 15 days of storage mesophilic count reached $7 \mathrm{log} \mathrm{CFU} / \mathrm{g}$ in unbled and 6 log CFU/g in bled seabass, and psychrotrophic count 8 log CFU/g in unbled and 7 log CFU/g in bled seabass (27), showing 1 log CFU/g difference between bled and unbled fish. Slowing down the growth of bacteria was even more pronounced in that research, with $2 \log$ CFU/g reduction in bled compared to unbled common carp. Additionally, bacterial counts in bled fillets did not exceed 7 log CFU/g as upper acceptable limit for mesophilic count in fish meat (34). Despite this limit, 6 log CFU/g has been shown as critical point in fish meat storage (35), which was not exceeded in bled carp until day 12 of storage. This reduction was also likely responsible for the improvement of sensory acceptability of raw fillets of bled carp, as microbial activity is responsible for the development of fishy odour, discolouration and slime development.

The data in Table 4 show that both the mesophilic and psychrotrophic bacteria increased with the same trend, and reached comparable logarithmic values. This showed that the bacteria in both the bled and unbled carp fillets can grow across a wide temperature range, and that it was the same population of bacteria that grew at both temperatures. From this, it would appear that these were bacteria of the genus Pseudomonas, which are the main bacterial spoilers of fish meat stored under refrigerated aerobic conditions $(36,37)$. This was later on confirmed by isolation of strains, determination of their phenotypic characteristics and sequencing for bacterial identification (Sterniša M and Smole Možina S, unpublished). In addition to their growth across a wide temperature range, the importance of the presence of iron has also been highlighted for these bacteria $(38,39)$. Therefore, in the present study, the reduction in haem, and thus also in iron, positively contributed (mesophilic count $\mathrm{R}=0.686, \mathrm{p}=0.001$; psychrotrophic count $\mathrm{R}=0.808, \mathrm{p}<0.001)$ to the reduced growth rate of these bacteria in the raw fillets of the bled carp.

\section{CONCLUSION}

To conclude, the bleeding of common carp affected all of the parameters investigated in the present study. The reduction in haem in the raw carp fillets as a result of bleeding improved the colour characteristics and sensory qualities, and it also slowed down lipid oxidation and growth of bacteria, which indicates that the residual blood is a promoter of lipid oxidation and bacterial growth in these raw carp fillets. Apart from higher
$L^{*}$ (lightness) and lower $a^{*}$ (redness) and $b^{*}$ (yellowness) of the raw bled carp fillet meat, there was less discolouration. Together with the improved sensory qualities, this positively contributed to the general acceptability of common carp investigated in this study. The inclusion of bleeding in the processing of common carp fillets might thus provide meat of better quality that is more acceptable to consumers. However, there remains the need to determine and optimise the best bleeding technique during the slaughter of common carp. In addition, the bleeding has the potential to prolong the shelf-life of common carp fillets, which should be further investigated.

\section{ACKNOWLEDGEMENTS}

The authors wish to thank Kateřina Fulinova and Michal Kubik for their help with sample preparation and analyses. MS wishes to personally thank Sabine Sampels for useful advice and support.

\section{FUNDING}

This study was supported financially by the Ministry of Education, Youth and Sports of the Czech Republic, through the projects CENAKVA (No. CZ.1.05/2.1.00/01.0024) and CENAKVA II (No. LO1205, under the NPU I programme), by the Grant Agency of South Bohemia in České Budějovice (GAJU 060/2016/Z), and by the Ministry of Agriculture of the Czech Republic (No. QJ1510119).

\section{REFERENCES}

1. Fishery and aquaculture statistics. FAO yearbook. Rome, Italy: Food and Agriculture Organization (FAO); 2018. Available from: http://www.fao.org/3/i9942t//9942T.pdf.

2. Sterniša M, Mraz J, Smole Možina S. Microbiological aspects of common carp (Cyprinus carpio) and its processing - Relevance for final product quality: A review. Aquac Int. 2016; 24(6):1569-90.

https://doi.org/10.1007/s10499-016-0051-8

3. Rahmanifarah K, Shabanpour B, Sattari A. Effects of clove oil on behavior and flesh quality of common carp (Cyprinus carpio L.) in comparison with pre-slaughter $\mathrm{CO}_{2}$ stunning, chilling and asphyxia. Turkish J Fish Aquat Sc. 2011;11:139-47. https://doi.org/10.4194/trjfas.2011.0118

4. Varga D, Szabó A, Hancz C, Jeney Z, Ardó L, Molnár M, et al. Impact of handling and pre-mortal stress on the flesh quality of common carp (Cyprinus carpio L.). Isr J Aquac. 2014; 66:1-6.

5. Daskalova AH, Pavlov Al. Effect of two stunning methods on postmortem muscle $\mathrm{pH}$ and meat quality of common carp (Cyprinus carpio). Bulg J Vet Med. 2015;18(1):83-90. https://doi.org/10.15547/bjvm.822

6. Richards MP, Hultin HO. Contributions of blood and blood components to lipid oxidation in fish muscle. J Agric Food Chem. 2002;50(3):555-64. https://doi.org/10.1021/jf010562h 
7. Sohn JH, Ushio H, Ishida N, Yamashita M, Terayama M, Ohshima T. Effect of bleeding treatment and perfusion of yellowtail on lipid oxidation in post-mortem muscle. Food Chem. 2007;104(3):962-70.

https://doi.org/10.1016/j.foodchem.2006.12.062

8. ThiansialakulY, Benjakul S, Richards MP. Effect of myoglobin from Eastern little tuna muscle on lipid oxidation of washed Asian seabass mince at different $\mathrm{pH}$ conditions. J Food Sci. 2011;76(2):C242-9.

https://doi.org/10.1111/j.1750-3841.2010.01992.x

9. Lee SK, Tatiyaborworntham N, Grunwald EW, Richards MP. Myoglobin and haemoglobin-mediated lipid oxidation in washed muscle: Observations on crosslinking, ferryl formation, porphyrin degradation, and haemin loss rate. Food Chem. 2015;167:258-63.

https://doi.org/10.1016/j.foodchem.2014.06.098

10. Wandersman C, Delepelaire P. Bacterial iron sources: From siderophores to hemophores. Annu Rev Microbiol. 2004;58: 611-47.

https://doi.org/10.1146/annurev.micro.58.030603.123811

11. Maqsood S, Benjakul S, Kamal-Eldin A. Haemoglobin-mediated lipid oxidation in fish muscle: A review. Trends Food Sci Technol. 2012;28(1):33-43.

https://doi.org/10.1016/j.tifs.2012.06.009

12. ISO 8589:2007. Sensory analysis - General guidance for the design of test rooms. Geneva, Switzerland: International Organization for Standardization (ISO); 2001.

13. Masilko J, Zajíc T, Hlaváč D. The culture system affects organoleptic properties and lipid composition of common carp (Cyprinus carpio L.) meat. J Texture Stud. 2015;46(5):345-52. https://doi.org/10.1111/jtxs.12134

14. ISO 6658:2005. Sensory analysis - Methodology - General guidance. Geneva, Switzerland: International Organization for Standardization (ISO); 2005.

15. O'Grady MN, Monahan FJ, Brunton NP. Oxymyoglobin oxidation and lipid oxidation in bovine muscle - Mechanistic studies. J Food Sci. 2001;66(3):386-92.

https://doi.org/10.1111/j.1365-2621.2001.tb16115.x

16. Olsen SH, Sorensen NK, Stormo SK, Elvevoll EO. Effect of slaughter methods on blood spotting and residual blood in fillets of Atlantic salmon (Salmo salar). Aquaculture. 2006; 258(1-4):462-9.

https://doi.org/10.1016/j.aquaculture.2006.04.047

17. Hornsey HC. The colour of cooked cured pork. I. - Estimation of the nitric oxide-haem pigments. J Sci Food Agric. 1956;7(8):534-40.

https://doi.org/10.1002/jsfa.2740070804

18. Shanta NC, Decker EA. Rapid, sensitive, iron-based spectrophotometric methods for determination of peroxide values of food lipids. J AOAC Int. 1994;77(2):421-4.

19. Miller DD. Lipid peroxidation. In: Miller DD, editor. Food chemistry: A laboratory manual. New York, NY, USA: Wiley-Interscience, John Wiley \& Sons; 1998. pp. 57-67.
20. ISO 17410:2001. Microbiology of food and animal feeding stuffs - Horizontal method for the enumeration of psychrotrophic microorganisms. Geneva, Switzerland: International Organization for Standardization (ISO); 2001.

21. ISO 4833-1:2013. Microbiology in the food chain. Horizontal method for the enumeration of microorganisms - Part 1: Colony count at 30 degrees $C$ by pour plate technique. Geneva, Switzerland: International Organization for Standardization (ISO); 2013.

22. Statistical Analysis. A guide on dissertation and thesis statistics in SPSS. Clearwater, FL, USA: Statistics Solutions; 2011. Available from: http://www.statisticssolutions.com/ spss-manual/.

23. Kemp SE, Hollowood T, Hort J, editors. Sensory Evaluation: $A$ practical handbook. London, UK: John Wiley \& Sons; 2009. https://doi.org/10.1002/9781118688076

24. SPSS Statistics, V23, IBM Corporation, North Castle, NY, USA; 2015. Available from: https://www-01.ibm.com/support/ docview.wss? uid=swg24038592.

25. Olsen SH, Joensen S, Tobiassen T, Heia K, Akse L, Nilsen H. Quality consequences of bleeding fish after capture. Fish Res. 2014;153:103-7.

https://doi.org/10.1016/j.fishres.2014.01.011

26. Roth B, Torrissen OJ, Slinde E. The effect of slaughtering procedures on blood spotting in rainbow trout (Oncorhynchus mykiss) and Atlantic salmon (Salmo salar). Aquaculture. 2005,250(3-4):796-803.

https://doi.org/10.1016/j.aquaculture.2005.03.010

27. Maqsood S, Benjakul S. Effect of bleeding on lipid oxidation and quality changes of Asian seabass (Lates calcarifer) muscle during iced storage. Food Chem. 2011;124(2):459-67. https://doi.org/10.1016/j.foodchem.2010.06.055

28. Digre H, Erikson U, Misimi E, Standal IB, Gallart-Jornet L, Riebroy S, Rustad T. Bleeding of farmed Atlantic cod: residual blood, color, and quality attributes of postrigor fillets as affected by perimortem stress and different bleeding methods. J Aquat Food Prod T. 2011;20(4):391-411. https://doi.org/10.1080/10498850.2011.576380

29. Terayama M, Yamanaka H. Effect of bleeding on the quality of skipjack. Nippon Suisan Gakk. 2000;66(5):852-8. https://doi.org/10.2331/suisan.66.852

30. Ando M, Nishiyabu A, Tsukamasa Y, Makinodan Y. Post-mortem softening of fish muscle during chilled storage as affected by bleeding. J Food Sci. 1999;64(3):423-8. https://doi.org/10.1111/j.1365-2621.1999.tb15056.x

31. Sakai T, Ohtsubo S, Minami T, Terayama M. Effect of bleeding on hemoglobin contents and lipid oxidation in the skipjack muscle. Biosci Biotechnol Biochem. 2006;70(4):1006-8. https://doi.org/10.1271/bbb.70.1006

32. Chaijan M, Benjakul S, Visessanguan W, Faustman C. Changes of pigments and colour of sardine (Rastrelliger kanagurta) muscle during iced storage. Food Chem. 2005;93(4):607-17. https://doi.org/10.1016/j.foodchem.2004.10.035 
33. Thiansilakul Y, Benjakul S, Grunwald EW, Richards MP. Retardation of myoglobin and haemoglobin-mediated lipid oxidation in washed bighead carp by phenolic compounds. Food Chem. 2012;134(2):789-96.

https://doi.org/10.1016/j.foodchem.2012.02.182

34. Microorganisms in foods 2: Sampling for microbiological analysis: Principles and scientific applications, vol. 2. International Commission on Microbiological Specifications for Food (ICMSF). Toronto, Canada: University of Toronto Press; 1986.

35. Özogul F, Polat A, Özogul Y. The effects of modified atmosphere packaging and vacuum packaging on chemical, sensory and microbiological changes of sardines (Sardina pilcardus). Food Chem. 2004;85(1):49-57.

https://doi.org/10.1016/j.foodchem.2003.05.006

36. Parlapani FF, Boziaris IS. Monitoring of spoilage and determination of microbial communities based on 16S rRNA gene sequence analysis of whole sea bream stored at various temperatures. LWT - Food Sci Technol. 2016;66:553-9.

https://doi.org/10.1016/j.lwt.2015.11.007

37. Zhang Y, Li Q, Li D, Liu X, Luo Y. Changes in the microbial communities of air-packaged and vacuum-packaged common carp (Cyprinus carpio) stored at $4{ }^{\circ} \mathrm{C}$. Food Microbiol. 2015;52:197-204.

https://doi.org/10.1016/j.fm.2015.08.003

38. Champomier-Vergès MC, Stintzi A, Meyer JM. Acquistition of iron by the non-siderophore-producing Pseudomonas fragi. Microbiology. 1996;142:1191-9.

https://doi.org/10.1099/13500872-142-5-1191

39. Ercolini D, Casaburi A, Nasi A, Ferrocino I, Di Monaco R, Ferranti $\mathrm{P}$, et al. Different molecular types of Pseudomonas fragi have the same overall behaviour as meat spoilers. Int J Food Microbiol. 2010;142(1-2):120-31.

https://doi.org/10.1016/j.ijfoodmicro.2010.06.012 